\title{
Comparison of Civil Service Reform in the United States and Korea: Central Personnel Agencies and Senior Civil Service Systems*
}

\author{
Soonyoung Choi***
}

\begin{abstract}
Recent changes to the Korean civil service system, such as the introduction of the Senior Civil Service system in 2006 and the elimination of the Civil Service Commission in 2008, superficially resemble changes introduced by the Civil Service Reform Act of 1978 in the United States. This study compares the structures and characteristics of the two countries' civil service systems, their reforms, and the political context and processes by which reform legislation came to pass. Based on this comparison, policy implications are drawn for improving the Korean civil service system.
\end{abstract}

Keywords: central personnel agency, Senior Executive Service, Senior Civil Service, Civil Service Reform Act of 1978, National Civil Service Act

\section{INTRODUCTION}

The Korean government has tried to introduce a public administration system based on the United States system since its foundation in 1948. The civil service system, as a subsystem of public administration, has therefore been influenced by the US system, which is based on shared powers and under which public servants are accountable both to the president and to Congress.

The Korean government adopted the American system of presidential government with its separation of powers among the legislative, executive, and judicial branches. Korea experienced strong presidential governments during its period of governmentdriven rapid economic growth. After the ninth revision of its Constitution in 1987, the Korean system became more characterized by shared powers than before. The president

\footnotetext{
* I would like to thank Prof. Beryl Radin at American University for her insightful comments on earlier drafts of this paper.

** Soonyoung Choi is a research fellow at the Korea Institute of Public Administration. Email: csyoung@kipa.re.kr, csyoung1020@naver.com.
}

Manuscript received June 8, 2012; out for review June 26, 2012; review completed August 14, 2012; accepted August 21, 2012.

The Korean Journal of Policy Studies, Vol. 27, No. 3 (2012), pp. 101-123.

(C) 2012 by the GSPA, Seoul National University 
is limited to one five-year term of office. With changes in president, the personnel system has experienced concomitant changes.

Recent civil service system changes, such as the introduction of the Senior Civil Service (SCS) in 2006 and the elimination of the Civil Service Commission (CSC) in 2008, superficially resemble those brought about in the United States by the Civil Service Reform Act of 1978. This article explores the ways in which recent Korean civil service reforms are similar to and different from those introduced in the United States.

In Korea, the introduction of the SCS and the elimination of the CSC were carried by the Rho Moo-Hyun and Lee Myong-Bak governments, respectively, two administrations with different political points of view. Similar reforms in the United States were implemented as a package by the administration of President Jimmy Carter in 1978. Comparing the two countries' civil service systems, this article focuses on the central personnel agencies and the senior civil service systems. Such an evaluation may make it possible to gain a better understanding of these reform initiatives, conduct more appropriate comparisons, and identify policy implications.

The US public service has never been an elite service, and the United States in general values the private sector more than the public sector. In contrast, the Korean system has been an elite service, and in the past, Korea valued the public sector more than the private sector, although this is currently changing. These very different assumptions about the role of the public sector make comparison difficult.

Civil service reforms serve as vehicles to establish and defend political actors' standing and capacity to influence the authoritative allocation of values (Nigro, Nigro $\&$ Kellough, 2007, p. 305). They may produce shifts in the internal political dynamics of a central personnel agency and other departments and in the balance of power among agencies and branches of government (Nigro, Nigro \& Kellough, 2007, p. 305), especially when there is structural reorganization or modification of the authority and jurisdiction of a personnel agency. Accordingly, the background from which civil service reforms emerged, the political dynamics and administrative strategy employed in the reform process, and the values that drove the reforms need to be explored in order to get a better understanding of the reforms.

\section{CIVIL SERVICE SYSTEM CHANGES IN THE UNITED STATES AND KOREA}

The most significant institutional changes to the Korean civil service system were the creation of the CSC in 1999, its elimination in 2008, and the adoption of the SCS 
in 2006. Because this article is based on the premise that the most important recent Korean civil service system changes resemble those of the Civil Service Reform Act, it is necessary to explore the recent major changes in the Korean civil service system in detail.

Debates on values, theoretical underpinnings, and objectives provide common analytical lenses related to policy perspectives that underlie the development of reform efforts, often reflecting ideological differences among partisans of change when comparing both the civil service reform initiatives and the civil service system (cf. Radin, 1997, p. 12). In investigating the similarities and differences of civil service reform efforts in the United States and Korea, political contexts and backgrounds and the processes of their reform initiatives provide important frames to understand how the legislation came to pass. Also important are the structures and characteristics of the central personnel agencies and senior civil service systems.

\section{Recent Institutional Changes in the Korean Civil Service System}

The CSC's existence was determined more by political dynamics than by an analytical rationale. It was created in 1999 under the power of the progressive political party and eliminated after the inauguration of the conservative Lee administration in 2008. The Lee administration established the Ministry of Public Administration and Security (MOPAS) (www.mopas.go.kr) by integrating the Ministry of Government Administration and Home Affairs, the CSC, the National Emergency Planning Commission, and the national informatization strategy functions of the Ministry of Information and Communication.

Another major change was the establishment of the SCS in July 2006 as part of an effort to increase the competitiveness and openness of the government and the competency of staff filling different job specialties.

\section{Comparison of the US Civil Service Reform Act and Recent Changes in Korea}

The elimination of the Civil Service Commission and its replacement by the Office of Personnel Management (OPM) in the United States, and the elimination of the CSC and its replacement by MOPAS in 2008 in Korea, had similar goals but different political backgrounds, processes, and structures. The US Civil Service Reform Act emphasized management flexibility and political and public responsiveness (Brook \& King, 2008, p. 205; Nigro \& Nigro, 1986, pp. 20-26) rather than political neutrality.

Passage of the Civil Service Reform Act took place against a background of prevail- 
ing public anti-bureaucratic sentiment and a sense in Congress that the time for civil service reform had come (Nigro, 1979, pp. 205-206). Many legislators were concerned that the administrative agencies were not sufficiently responsive to legislative requests (Nigro \& Nigro, 1986, p. 19). A long-standing dissatisfaction of presidents, governors, and other chief executives is that the civil service extends so far upward in the administrative hierarchy that there are too few exempt positions they can fill with persons in whose loyalty to their policies they can trust (Nigro \& Nigro, 1986, p. 24). The issue here is not political spoils but rather the ability to be in control of the administrative branch, to carry out electoral mandates, and to be able to deal effectively with any bureaucratic sabotage by career officials (Nigro \& Nigro, 1986, p. 24). As a result of these concerns, such values as management flexibility and political and public responsiveness were embedded in the Civil Service Reform Act (Nigro \& Nigro, 1986, pp. 20-26).

In Korea, the goals of the elimination of the CSC could be said to be political responsiveness, efficiency, and management flexibility, similar to those of the Civil Service Reform Act. The most important reason for the consolidation of the CSC into MOPAS was the Lee administration's pursuit of small government.

President Carter's proposals for civil service reform formed the background of the Civil Service Reform Act. Carter's recommendations were politically bold in that they proposed abolishing a 95-year-old agency (Nigro, 1979, pp. 204-205). The political background of the elimination of the CSC in Korea was the inauguration of a new government that enjoyed using the rhetoric of more efficient government and better economic growth.

On the other hand, the political background of the introduction of the SCS in Korea was the reform initiative that the progressive President Rho intended to engage in with the goal of more competent government. The introduction of the SCS is also considered as a diffusion of the Civil Service Reform Act among member countries of the Organisation for Economic Co-operation and Development (Lah \& Perry, 2008, p. 282; NamKoong, 2006, p. 16). Korean administrative reformers have sometimes tried to imitate US initiatives such that "American administrative reformers have behaved much like the purveyors of the fashion world" (Radin, 1997, p. 15). In addition, the amendment of the Korean National Civil Service Act to establish the SCS in 2006 seemed to be based on a political situation in which the progressive political party gained a majority of seats in the election of members of the National Assembly after President Rho's impeachment during his midterm period.

There were significant differences in the decision-making processes that led to the US and Korean reforms. In the United States, the administration's political strategy was to develop support within the executive branch, in the country as a whole, and in 
Congress (Nigro, 1979, p. 207). Thorough planning and careful attention to detail characterized this effort, in which Civil Service Commission Chairman Alan K. Campbell played a prominent role (Nigro, 1979, p. 207). The process of building support within the executive branch started long before submission of the legislation to Congress (Nigro, 1979, p. 207). After naming Campbell as chairman and Jule M. Sugarman as vice-chairman of the Commission, Carter told them to work with the Office of Management and Budget on plans for civil service reform, and that he wanted the "bulk of the people in this effort" to be career employees (Nigro, 1979, pp. 207-208).

One of the most significant decisions made in carrying out this project was to hold 17 hearings at field locations throughout the country (about 87 percent of all federal employees were stationed in the field). At these hearings, agency field personnel testified and gave their opinions as to what problems existed and what changes were needed in the personnel system (Nigro, 1979, p. 208). Option papers were debated in town hall meetings and reviewed by government agencies (Brook \& King, 2008, p. 207).

In contrast, the elimination of the CSC in Korea in 2008 involved political topdown decision-making (Cho \& Hwang, 2009, pp. 210-211; Park, 2009, pp. 11-12) that reflected the opinions of the Presidential Transition Committee and lacked a process of building support. A few reform politicians led the process of merging ministries. It is presumed that the reform politicians regarded the rigid system of civil service rules as a cause of inefficiency (cf. Lee, 2008, p. 35). The bureaucratization of the CSC led to widespread dissatisfaction in other departments, resulting eventually in its elimination (Lee, 2008, p. 28). The white book for government reorganization (2008) mentioned that the establishment of the MOPAS by merging the Ministry of Government Administration and Home Affairs, CSC, and other agencies was intended to resolve such difficulties as policy inconsistency and conflict due to the separation of personnel management and organization management (Park, 2011, p. 4). The elimination of the CSC was intended to delegate personnel authority from the central personnel agency to other departments and agencies (Yun, 2009, p. 302). However, the reform process was drastic and based on insufficient debate and reflection (Lee, 2008, p. 40; Lee \& Im, 2009, p. 1; Park, 2011, p. 11; Yun, 2009, pp. 298, 303). The actual causes of the elimination of the CSC seemed to be the return of the conservatives to political power and their denial of the achievements of previous administrations, which often occurs during political regime change.

One of the similarities between the US Civil Service Reform Act and the civil service reform in Korea is that both provided more latitude for agency management in personnel matters (cf. Nigro, 1979, p. 200). The Civil Service Reform Act authorized the OPM director to delegate functions to executive agency heads, except for his or her authority to oversee competitive examinations for positions with requirements 
Table 1. Civil Service Reform in the United States and Korea

\begin{tabular}{l|l|l}
\hline & \multicolumn{1}{|c|}{ US Civil Service Reform Act } & \multicolumn{1}{c}{ Korean civil service reform } \\
\hline $\begin{array}{l}\text { Institutional } \\
\text { changes }\end{array}$ & $\begin{array}{l}\text { Elimination of the Civil Senvice } \\
\text { Commission and its replacement by the } \\
\text { Office of Personnel Management and the } \\
\text { Merit System Protection Board } \\
\text { Introduction of the Senior Executive } \\
\text { Service }\end{array}$ & $\begin{array}{l}\text { Elimination of the Civil Service } \\
\text { Commission and creation of the Ministry of } \\
\text { Public Administration and Security } \\
\text { Introduction of the Senior Civil Service }\end{array}$ \\
\hline Key goals & $\begin{array}{l}\text { Management flexibility } \\
\text { Political and public responsiveness } \\
\text { Accountability }\end{array}$ & $\begin{array}{l}\text { Political responsiveness and efficiency } \\
\text { Enhancing competency and effectiveness }\end{array}$ \\
\hline context & $\begin{array}{l}\text { President Carter's proposal } \\
\text { Climate in Congress conducive to civil } \\
\text { service reform } \\
\text { Prevailing public anti-bureaucratic mood }\end{array}$ & $\begin{array}{l}\text { Political regime change } \\
\text { to merge ministries } \\
\text { Progressive Rho administration's initiative } \\
\text { to promote more competent government }\end{array}$ \\
\hline Process & $\begin{array}{l}\text { Thorough planning and support building, } \\
\text { including debates, field hearings, and other } \\
\text { mechanisms for gathering opinions }\end{array}$ & $\begin{array}{l}\text { Top-down political decision-making by a } \\
\text { new administration without sufficient } \\
\text { debate or building of support within the } \\
\text { executive branch and related groups }\end{array}$ \\
\hline Characteristics & $\begin{array}{l}\text { More latitude for agency management in } \\
\text { personnel matters }\end{array}$ & $\begin{array}{l}\text { Delegation of personnel authority from a } \\
\text { central agency to individual departments } \\
\text { and agencies }\end{array}$ \\
\hline
\end{tabular}

Source : Nigro \& Nigro (1986); Nigro (1979).

that were the same for multiple federal agencies (Nigro \& Nigro, 2nd edition, p. 23). The Korean civil service reform also delegated personnel authority from the central personnel agency to other departments and agencies in order to cope with the rapidly changing environment. An important example of this was the delegation of recruitment authority for positions unique to individual departments or agencies. This involved the expansion of a special recruitment program intended to bring experts in various fields into public service. This program has been administered at departmental discretion. The elimination of the CSC seems to have been intended to delegate personnel authority from the central personnel agency to other departments or agencies and to have succeeded in this regard.

\section{Comparison of the Central Personnel Agencies}

The US Civil Service Reform Act replaced the country's Civil Service Commission with the OPM, directly under the president, and the independent, quasi-judicial Merit 
Systems Protection Board (MSPB) (http://www.mspb.gov), responsible for hearing appeals and functioning as a watchdog. The president appoints the OPM director and three members of the MSPB as well as a special counsel, all subject to Senate confirmation. No more than two MSPB members may belong to the same political party. MSPB members can be removed by the president only for misconduct, inefficiency, neglect of duty, or malfeasance. The special counsel to the MSPB investigates charges of prohibited personnel practices and recommends corrective action to the agency and to the OPM, prosecutes violators of civil service rules and regulations, and enforces the Hatch Act (Nigro, 1979, p. 197-198; Nigro \& Nigro, 1986, p. 21).

The MSPB assumed the employee appeals function of the Civil Service Commission and was given new responsibilities to perform merit system studies and to review the significant actions of the OPM. Although originally established as an office of the MSPB, the Office of Special Counsel now functions independently as a prosecutor of cases before the Board. In July 1989, it became an independent executive branch agency.

The functions of the MSPB and OPM are obviously interrelated in important ways, which explains why they were created together to replace the old Civil Service Commission (West \& Durant, 2000, p. 112). The OPM occasionally challenges the MSPB's decisions in federal court. The relationship between the two agencies can best be characterized as one of cordial tension (West \& Durant, 2000, p. 112).

In Korea, the CSC was replaced by the MOPAS, which performs important functions in addition to personnel management. Within MOPAS, the Personnel Management Office was reassigned functions formerly performed by the CSC, which included serving as a central personnel agency.

Both the OPM and the MOPAS were established with the goal of increasing management flexibility, but they are different in terms of independence. Both the director of the OPM and the minister of the MOPAS are appointed by their respective presidents, but the director of the OPM is subject to Senate confirmation, while the minister of the MOPAS is not subject to confirmation by Congress. Korean public civil servants are accountable both to the president and the Congress, because sharing powers and balancing competing values are heavily emphasized in Korea.

The director of the OPM serves for a four-year term, while the minister of the MOPAS and the head of the Personnel Management Office are not guaranteed a fixed term of office but can be removed at their supervisor's discretion. Recent terms of office have been less than two years or even less than one year. This implies the possibility of politicizing the civil service system, resulting in leadership by "yes" people rather than the consideration of national and public interests and rational decision-making and implementation (cf. Nigro, 1979, p. 211). The US Civil Service Reform Act speci- 
fies that the OPM is an independent establishment in the executive branch, but Korea's National Civil Service Act contains no language regarding the independence of the central personnel agency.

In Korea, the agency corresponding to the MSPB is the Appeals Commission, established in 1963 (http://sochung.mopas.go.kr) under the MOPAS to hear public officials' appeals of agency-adverse actions, including disciplinary actions and nonfeasance. The Appeals Commission is composed of five to seven permanent members appointed by the president, with the MOPAS minister's recommendation. The term of office of each member is three years, compared to seven years for members of the MSPB. The National Civil Service Act designates that the chief commissioner of the Appeals Commission is a political appointee, and a few temporary members can be appointed to the Appeals Commission when necessary.

MSPB members may not serve two consecutive terms, but they may continue to serve after their term expires until a successor is appointed. Members of the Appeals Commission in Korea can serve a second consecutive term.

The structure of the MSPB reflects Congress's desire to insulate its functions from undue political influence (West \& Durant, 2000, p. 112). An important feature of the MSPB is the Office of Special Counsel with its investigative and prosecutorial responsibilities (Campbell, 1978a, p. 100) and its jurisdiction over all prohibited personnel practices and authority to independently initiate investigations to protect the public interest (Campbell, 1978a, p. 100). The special counsel has a term of five years. The Civil Service Reform Act stipulates that the special counsel shall receive any allegation

Table 2. Comparison of the US Office of Personnel Management and Korean Personnel Management Office

\begin{tabular}{l|l|l}
\hline & \multicolumn{1}{|c|}{$\begin{array}{c}\text { US Office of Personnel } \\
\text { Management }\end{array}$} & \multicolumn{1}{|c}{$\begin{array}{c}\text { Korean Personnel Management } \\
\text { Office }\end{array}$} \\
\hline $\begin{array}{l}\text { Legislative confirmation } \\
\text { required for appointment } \\
\text { of director? }\end{array}$ & Yes & No \\
\hline Structure and function & $\begin{array}{l}\text { A central agency in which } \\
\text { personnel management functions } \\
\text { are vested }\end{array}$ & $\begin{array}{l}\text { An administrative department in } \\
\text { which both personnel management } \\
\text { and other functions are vested }\end{array}$ \\
\hline Deputy director & $\begin{array}{l}\text { Serves with advice and consent of } \\
\text { the Senate }\end{array}$ & No deputy director position \\
\hline Director's term of office & Four years & No fixed term \\
\hline Independence & $\begin{array}{l}\text { Independence established under } \\
\text { the Civil Service Reform Act }\end{array}$ & No law establishing independence \\
\hline
\end{tabular}

Sources: Civil Service Reform Act of 1978; Nigro \& Nigro (1986); Shafritz et al. (1992). 
Table 3. Comparison of the USMerit System Protection Board and Korean Appeals Commission

\begin{tabular}{l|l|l}
\hline $\begin{array}{l}\text { Year of creation and } \\
\text { legal basis }\end{array}$ & US M erit System Protection Board & \multicolumn{1}{|c}{ Korean Appeals Commission } \\
\hline Independence and role & $\begin{array}{l}\text { Independent, quasi-judicial agency } \\
\text { in the executive branch that serves } \\
\text { as the guardian of the federal merit } \\
\text { system and investigates charges of } \\
\text { prohibited personnel practices }\end{array}$ & $\begin{array}{l}\text { Quasi-independent, quasi-judicial } \\
\text { agency under the M inistry of Public } \\
\text { Administration and Security to which a } \\
\text { public employee against whom a } \\
\text { disciplinary action or another adverse } \\
\text { action is taken is entitled to appeal }\end{array}$ \\
\hline Number of members & Three & Five to seven \\
\hline $\begin{array}{l}\text { Legislative confirmation } \\
\text { of appointees required? }\end{array}$ & Yes & No \\
\hline Term of office & Seven years & Three years \\
\hline Characteristics & $\begin{array}{l}\text { Special counsel (term of office is } \\
\text { five years) named by the president } \\
\text { with Senate confirmation }\end{array}$ & \\
\hline
\end{tabular}

Sources: Korean National Civil Service Act; US Civil Service Reform Act.

of a prohibited personnel practice and shall investigate the allegation to the extent necessary to determine whether there are reasonable grounds to believe that a prohibited personnel practice has occurred, exists, or is to be taken.

In Korea, appointments to the Appeals Commission require no confirmation in Congress. The existence of the Appeals Commission is not sufficient to prevent a merit principle from being abused, because the Commission hears and adjudicates only appeals initiated by government officials. Many people in Korea who believe that a merit principle has been violated are not inclined to go to adjudication.

\section{Comparison of the Senior Civil Service Systems}

The Civil Service Reform Act established the Senior Executive Service (SES) to deliver the flexibility needed by agencies to recruit and retain the highly competent and qualified executives needed to provide a more effective management of agencies and their functions and a more expeditious administration of the public business. The objectives of the SCS in Korea are to improve the core management of the government by holding senior managers accountable for individual and organizational performance, selecting and developing senior managers from an expanded government-wide pool of talent, and making senior levels more open to talented individuals from the lower ranks and from the outside (Namkoong, 2006, p. 16). The SES in the United States 
and the SCS in Korea are similar in that a primary objective of their creation was to improve government operations (cf. Rosen, 1981, p. 203; Yeager, 1987, p. 417). Although the introduction of the SCS in Korea is regarded as a diffusion of the US concept of the SES, some of the assumptions and contents of the two reforms are different.

The theoretical underpinnings of the SES can be summarized as follows (Perry \& Miller, 1991; Ring \& Perry, 1983, pp. 120-124). First, management has a common core, the elements of which can be universally applied, or nearly so. Based on this assumption, the architects of the SES intended to devise a single executive-level personnel system that would apply across the entire federal executive department structure to achieve the goal of improved management of executive positions (Ring \& Perry, 1983, p. 121). A unified executive personnel management system replaced the fragmented set of authorities that preceded the SES (Perry \& Miller, 1991, p. 555). Consistent with the objective of a single personnel system was the attempt to create, through the SES, a rank-in-person mobility system (Perry \& Miller, 1991, pp. 554-555; Ring \& Perry, 1983, p. 121).

Second, the basic belief underlying the design of the SES was that government agencies could be managed more like a private-sector organization. According to this assumption, it would be possible to motivate federal managers by using the same kind of techniques that, it was assumed, had been successful in motivating private sector managers. The performance effectiveness track in Buchanan's (1981) schematic was anticipated to provide rewards and punishments for achievements (Perry \& Miller, 1991, p. 556). The architects of the SES designed a system that rested, in large measure, on the premise that performance would be motivated by and linked to pay.

Third, the SES sought to meet the goals of improved control of management positions, improved managerial accountability and competence, and increased political control over the bureaucracy without the expense of merit system principles (Ring \& Perry, 1983, p. 124). In the United States, the SES system made it easier for chief executives and department heads to maintain control because SES members could be moved from one post to another and, since they were untenured, could be removed from the SES itself (Nigro \& Nigro, 1986, p. 25). In other words, the SES, as part of the reform, was designed to supply political executives with a carrot and stick to increase the receptivity of top bureaucratic managers to new policy-makers' wishes (Long, 1981, p. 305).

The SCS in Korea appears to have a similar theoretical basis in some respects. The belief that management has a common core made it possible to adopt an assessment center, which assesses SCS candidates based on competency models. SCS provisions for performance-based and job-analysis-based pay also seem to be based on the theory that individual performance levels could be linked to pay (consistent with the belief 
that government agencies could be managed more like private-sector organizations). Likewise, emphasis on open competition for SCS positions by candidates within and outside the government was based on the belief that civil service management could benefit from the private sector's business acumen.

SES appointments can be either career or noncareer. Career appointments are based on a competitive merit staffing process; candidates' executive qualifications are certified by the Qualifications Review Board; they are also open to individuals from outside the SES. Noncareer appointments are noncompetitive (http://www.opm.gov/ ses/references/glossary.asp). Under the Civil Service Reform Act, the total number of noncareer appointees in all agencies may not exceed 10 percent of the total number of Senior Executive Service positions.

The establishment of the Korean SCS focused on openness and competitiveness. Initially, SCS positions throughout the departments and agencies consisted of open competitive positions (open to candidates from within and outside government) (20\%), positions open to current government employees only (30\%), and autonomous promotion positions (promotions open only to employees within a given department) (50\%). As departments and agencies were merged after the inauguration of the new administration in 2008, the necessity for competition among departments and agencies decreased, job posting positions (competing among departments and agencies) were reduced to $15 \%$, and autonomous promotion positions were reduced to $65 \%$, resulting in increasing departmental discretion. Open competitive positions were maintained at $20 \%$. In practice, fewer than $50 \%$ of open competitive positions were filled with candidates from outside government, because many competent potential candidates from the private sector were not inclined to apply for government jobs because of their relatively low salaries, lack of job security, and other issues.

One of the differences between the Korean SCS and the US SES is their generalist versus specialist perspectives. Narrow classes of positions have characterized American classification plans (Nigro \& Nigro, 1986, p. 207). The SES was intended to bring a broad vision of a flexible corps at the top in order to overcome the narrow perspective attributed to these narrow position classifications and the intense specialization in professional fields and policy areas (Shafritz et al., 1992, p. 54). Therefore, the SES system introduced the rank-in-person concept (Nigro \& Nigro, 1986, p. 23, 109; Perry \& Miller, 1991, p. 555). The newly designed SES personnel system was created to increase the flexibility of political executives by placing greater emphasis on generalist skills (Ring \& Perry, 1983, p. 135), but the focus on mobility exposed its original limitations. As Rourke (1976) and Warwick (1975) have made clear, effective dealings with relevant congressional committees and client groups put a premium on staying with one agency and developing an area of functional expertise within it (Ring \& 
Perry, 1983, pp. 135-136). Moreover, this pattern of careers was deeply embedded in the federal service, and expectations of a sharp, immediate reversal may have been unrealistic from the beginning (Ring \& Perry, 1983, p. 136).

On the other hand, the Korean SCS was intended to combine a traditional rank-inperson approach with a job-based model to overcome the weaknesses of the generalist perspective. The SCS system in Korea is closer to the British system than to the US system. The necessity of introducing a generalist perspective into the system in Korea was not recognized, because the personnel system had traditionally been operated based on a rank-in-person concept. Far from introducing a generalist perspective, the SCS in Korea was designed to emphasize specialization in professional fields. Job analysis was conducted for SCS positions, which provided job descriptions and requirements in terms of the knowledge, skills, and abilities that were necessary to perform the job. SCS positions were evaluated and grouped into five categories based on the difficulty and responsibility of their duties. However, this resulted in rigidity of operation and lack of the flexibility the top executive positions needed. Therefore, in 2008, the SCS positions were grouped into two categories to give more flexibility to the positions-in effect returning to the rank-in-person system.

The US civil service system includes the Qualifications Review Board (http://www .opm.gov/ses/recruitment/qrbprocess.asp), which is an OPM-administered independent board of senior executives that assesses the executive core qualifications of SES candidates. OPM staff review each case to ensure that appropriate merit staffing procedures are followed, that the documentation of executive core qualifications is adequate, and that the required documents are completed. After reviewing and resolving any discrepancies, each case is forwarded to the Qualifications Review Board for action. Qualifications Review Boards are composed of three members of the SES, each from a different agency. At least two must be career appointees; if possible, one should have previously served as a Board member.

In Korea, the National Civil Service Act established a Qualifications Review Committee for appointments to the SCS. The Committee is composed of five to seven members including the chair, who is a MOPAS political appointee (the first of two vice ministers). Prior to the Qualifications Review Committee's review process, each agency's Promotion Review Board conducts a review process for the selection of a candidate for initial career appointment to the SCS. 
Table 4. Comparison of the USSenior Executive Service and the Korean Senior Civil Senvice

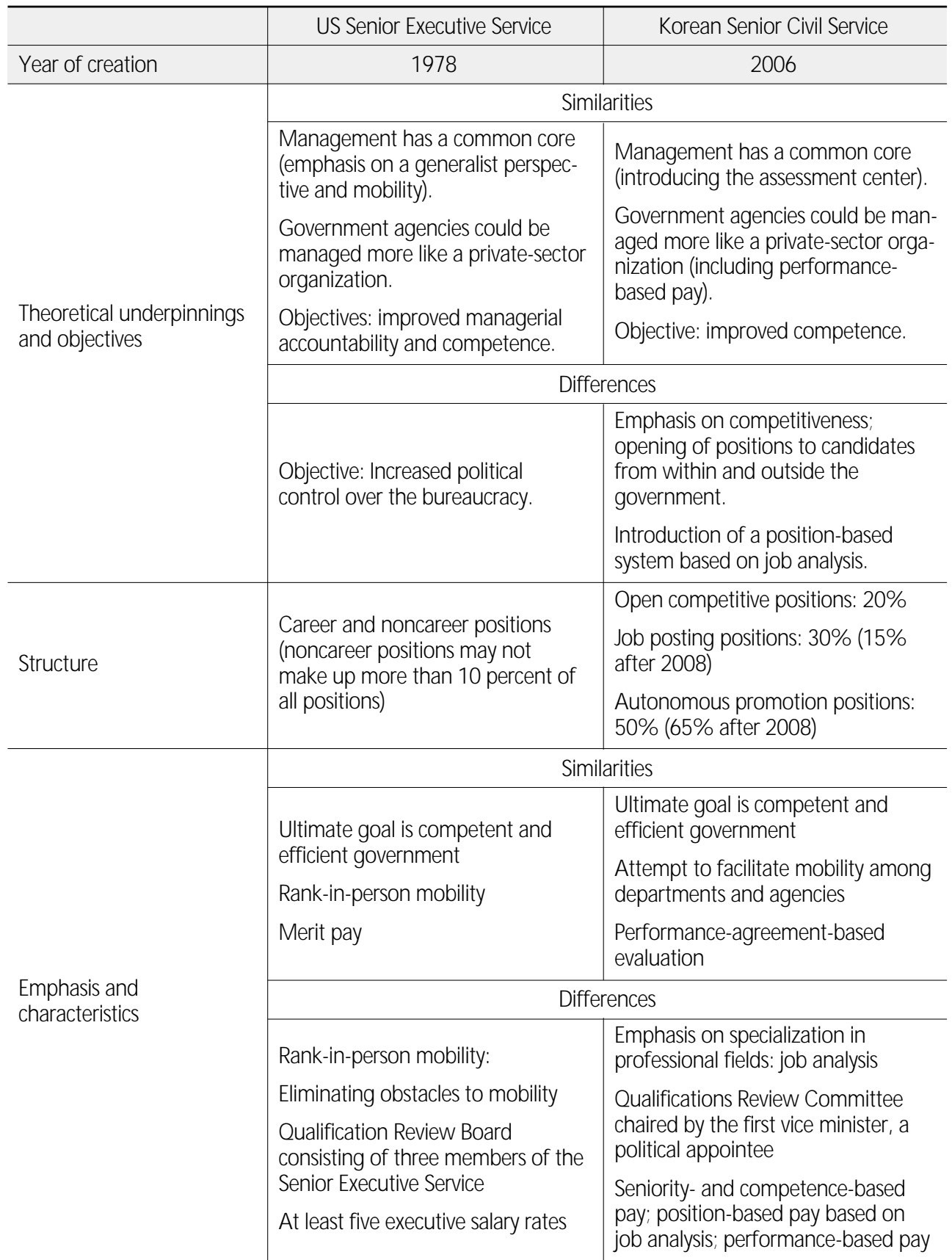

Sources: Civil Service Pay Regulation in Korea (2010); Nigro \& Nigro (1986); Perry \& Miller (1991); Ring \& Perry (1983); US Civil Service Reform Act. 


\section{POLICY IMPLICATIONS}

This article has focused on two aspects of the US and Korean civil service systems, the central personnel agency and the senior civil service, and their recent reforms. In order to draw policy implications by examining the similarities and differences of the two reforms, it is important to consider the time frame. Recent civil service system changes in Korea, including the adoption of the SCS in 2006 and the elimination of the CSC in 2008, superficially resemble those of the US Civil Service Reform Act of 1978, which has been in place for considerably longer. Strategies for improving the civil service system in Korea can be informed by the history of civil service reform efforts in the United States.

\section{Central Personnel Agency}

The history of the US federal civil service can be viewed as consisting of four rather distinct periods that suggest a long-term pattern of punctuated policy equilibrium: the era of the "spoils system," the time of the Pendleton Civil Service Act (1883-1978), the period beginning with the Civil Service Reform Act in 1978, and a fourth period, involving mostly incremental reform, around the 20th anniversary of the Civil Service Reform Act (Brook \& King, 2007, p. 400).

Although the central personnel agency established by the Civil Service Reform Act, the OPM, continues to exist, efforts to change the balance of power between it and other departments and agencies have been continuously pursued since 1978. The Civil Service Reform Act provided more latitude to agency managers in personnel matters (Nigro, 1979, p. 200). Since then, the direction of civil service reform in the United States has been toward decentralization of personnel authority, in the era of reinventing government of the National Performance Review led by US Vice President $\mathrm{Al}$ Gore as well as after the establishment of the National Commission on the Public Service, better known as the Volker Commission, in 1987 (Shaftriz et al., 1992, p. 92).

The Volker Commission also recommended that cabinet officers and agency heads should be given greater flexibility to administer their organizations, including greater freedom to hire and fire personnel (Shaftriz, et al., 1992, pp. 92-93). Reinventinggovernment initiatives are designed to give agency managers more discretion and authority, as would the emphasis on decentralizing hiring and firing decisions to agency managers and line operators (West \& Durant, 2000, p. 118). The Gore report specifically recommended that departments and agencies be given the authority to conduct recruitment and examinations (Thompson \& Radin, 1997, p. 12). In addition, the National Performance Review suggested that agencies be given more discretion in 
the areas of position classification, performance management and reward systems, and reducing the time required to terminate managers and employees for poor performance (Thompson \& Radin, 1997, p. 12). More recently, even the enactment of civil service reform in the Homeland Security Act in 2002 seemed to give a new cabinet-level department - the Department of Homeland Security — broad discretion and authority over personnel management (Brook \& King, 2007, p. 399).

Although decentralization has remained the trend in civil service reform efforts in the United States (except during the Bush and Clinton administrations), apprehension about weakening of merit principles has been raised at the same time by many scholars. Beginning before the enactment of the Civil Service Reform Act, there was much concern over possible politicization (Nigro, 1979, p. 214). West and Durant's (2000) findings raised a warning flag regarding decentralization giving agency managers more discretion and authority in personnel matters, arguing that indiscriminately delegating the protection of merit principles to agencies or to line operators within agencies is worrisome (West \& Durant, 2000, p. 119). During the periods of reinventing government (the Winter and Gore initiatives), even after the Civil Service Reform Act, a central matter of concern has become how best to protect merit principles in an era of fundamental change as the reformers offer prescriptions for reinventing public personnel systems at all levels of government (Barzelay, 1992; Condrey, 1998; Kettl, Ingraham, Sanders, and Horner, 1996; West \& Durant, 2000, p. 111). Broadly delegated authority might open the way to merit violations (Nigro, 1979, p. 215).

Ban and Red (1990) found that the data from surveys of personnel officials and rank-and-file civil servants suggest that some types of abuse of the merit system are taking place more frequently than the literature would have us believe (Ban \& Red, 1990, p. 67). The increased flexibility in the federal personnel system has been criticized as providing the potential for abuses based not on political affiliation, but rather on friendships, family ties, or other connections (Ban \& Red, 1990, p. 61, 67).

Although managers' desire for flexibility and speed in hiring is valid, the value of fair and open competition should never be ignored. An increase in departmental personnel authority is likely to damage equal employment opportunity. In Korea, the Appeals Commission's appellate function or the authority of the Board of Audit and Inspection for investigation is not enough to safeguard merit principles, because investigation is undertaken after abuse of the principles is alleged. ${ }^{1}$

1. The Korean Board of Audit and Inspection is a constitutional agency that serves under the President of the Republic but retains independence in performing its duties. The corresponding agency in the United States is the Government Accountability Office, an independent, nonpartisan agency that works for Congress. 
The Korean people are usually not willing to blow the whistle on something secret, illegal, or unjustifiable about their organization, and whistleblowers are at risk of being buried alive regarding their occupational activity. Whistleblower protections are limited primarily to corruption-related matters. The Appeals Commission in Korea primarily has authority to review and adjudicate appeals by public employees of a disciplinary action or other adverse action taken against them. Accordingly, candidates for public-sector jobs are not entitled to appeal to the Appeals Commission and are not in a position to know whether there has been a merit abuse in the process of recruitment and appointment.

One of the purposes of Korean civil service reform initiatives, including the elimination of the CSC and the merger of agencies in pursuit of small government, seemed to be to facilitate political and public responsiveness and control over the bureaucracy in order to achieve agency goals more efficiently. But the reform decision-making process lacked sufficient debate and support building even within the executive branch and related groups.

One of the most significant features of civil service reform in the United States was the process of debating and collecting a variety of opinions. One of the administration strategies in this regard was to hold hearings at field locations throughout the country. Later, although both the Department of Homeland Security and National Security Personnel System proposals emerged in a policy environment in which there was less consensus, neither of the laws establishing them specified any institutional or organizational changes (Brook \& King, 2008, pp. 207, 210).

Organizing the overall public personnel functions includes the challenge of realizing several incompatible values at once. An appropriate balance must be found between the flexibility needed to achieve agency purposes and fair treatment of employees by managers. A central personnel agency needs to be devised in an elaborated form to balance competing values. The relationship between the central personnel agency and other departments and agencies should involve checks and balances. Separation of power and checks and balances should be organizational principles within the executive branch as well as principles of the governing structure of the legislative, executive, and judicial branches.

Although the Civil Service Reform Act was intended to increase management flexibility, it was also equipped with solid devices for preserving the merit principle, such as fixed terms of office and the requirement for Senate confirmation of the appointment of the heads of the OPM and MSPB, and the establishment of the OPM's independence (http://www.opm.gov/ses/recruitment/qrbprocess.asp\#admin).

The Korean civil service does not have an independent central personnel agency with a legal guarantee of independence. Emphasis on managerial prerogatives at the 
agency level in extreme pursuit of efficiency could easily result in the sacrifice of the merit principle. Although the government in Korea has recently sought to increase management flexibility, protecting the merit principle should be a major consideration in civil service reform.

It is necessary to establish an independent central personnel agency in Korea to secure a merit system, scientific personnel management, and consistency and continuity of personnel management (see Lee, 2008, pp. 40-45). It is recommended that the independent central personnel agency have a form of committee and its members be subject to confirmation by Congress with a fixed term of office, like the Board of Audit and Inspection, to ensure that they retain independence and authority in performing their duties and that they are committed to their missions without concern about being removed from office.

A new form of central personnel agency (tentatively named the Civil Service Board) should be considered, like the Japanese National Personnel Authority, which is headed by three commissioners, appointed by the Cabinet with the approval of a parliamentary committee and the upper house. In addition, the Office of Special Counsel of the same figure that Campbell (1978a, p. 100) had presumed in the United States, should be established and should have the authority to independently initiate investigations to protect the merit principle and the public interest whether or not a case is appealed by a participant.

The independent central personnel agency should be responsible for filling positions and other personnel functions in the competitive service and in the executive branch. Personnel functions should be delegated in appropriate cases to the agencies to expedite processing appointments and other personnel actions. The independent personnel agency should be charged with the control and oversight of this delegation to protect merit against prohibited personnel practices and unsound management practices by the agencies. Decentralized and deregulated human resource management systems increase the need for accountability and oversight (Woodard, 2005, p. 115); thus, the central personnel agency's oversight role should be regarded as of fundamental importance.

\section{Senior Civil Service}

According to Ring and Perry (1983), US federal managers did not perceive that the SES would lead to improved individual or agency performance. This suggests that it is important in Korea to design the SCS in a way that ensures that it will lead to improved individual and organizational performance.

Policy implications and assumptions for redirecting and improving the SCS in 
Korea should be discussed and presented in association with the original major theoretical underpinning of the SES in the United States, which can be summarized in three categories: (1) management has a common core, (2) government agencies could be managed more like a private sector organization, and (3) there is increased political control over the bureaucracy (Ring \& Perry, 1983, pp. 120-124).

First, a single personnel system and a more effective use of executive-level personnel across the executive branch can be applied to the SCS based on the assumption that the top management has a common core. The assessment center that was adopted when the SCS was introduced seemed to be based on this assumption. It has assessed qualifications of SCS candidates based on competency models that have modified the executive core qualifications identified in terms of the key skills that are essential for success as a senior executive in the United States.

However, there is a difference between the SCS in Korea and the SES in the United States. Although the SES emphasizes a generalist perspective, the Korean SCS was intended to add to the job-based model that emphasized a specialist perspective, because the Korean civil service system was based on a rank-in-person mobility system and senior executives had already been functioning as generalists.

The SCS in Korea should focus on the improved management of executive positions and improved competencies of senior executives. Although specialization in professional fields needs to be emphasized in the operation of the SCS, a narrow perspective and rigid application of job analysis are not desirable in view of the assumption that management has a common core. Expertise needs to be developed at the middlemanager career stage, which can be seen as a specialist phase during which the employee concentrates on performing a specific set of assignments involving technical and work skills (Shafritz et al., 1992, p. 471). The possession of special or unique qualifications that indicate the likelihood of executive success should be a prerequisite for becoming a candidate for the SCS.

Second, Ring and Perry concluded, based on discussions with managers, that top federal managers did not appear to be as strongly motivated by contingent rewards as the architects of the SES had presumed (1983, p. 135). The data that the OPM has so far released on the second of its surveys indicates that attitudes have become more negative, especially on matters related to salary (Ring \& Perry, 1983, p. 139). According to Perry and Miller's (1991) study, however, the revised model provides support for the importance of performance rewards and appraisal accuracy as explanatory variables for both micro- and macro-level outcomes. The model suggests that rewards affect not only individual behavior but processes at the agency level as well (Perry \& Miller, 1991, p. 561).

There are three types of pay in Korea's SCS: seniority and competence-based pay 
(basic pay), position-based pay (depending on job analysis), and performance-based pay. This mixed pay structure seems to be better than a unitary pay structure, such as a pay band system dependent upon performance evaluation.

There are not many studies about the motivational effect of performance-based pay among senior civil servants, but it is unlikely that senior executives in Korea are strongly motivated by performance-based pay. Pay is just a one of a number of motivational factors including honor, respect, reputation, and advancement potential. In addition, the true public interest sometimes requires risk-taking or a long-term perspective at the executive level, and it is not easy for performance-based pay to motivate these kinds of behaviors.

These considerations suggest that it is necessary for the architects of the SCS in Korea to provide senior civil servants with the tools needed to make a true rewards system function, based on questioning and reflection about what can motivate highlevel public officials to do their best to commit to an organizational mission. A true rewards system that can motivate high-level officials requires a fair, accurate, balanced, and certified evaluation system. Good standards are the crucial factors in making the SES operational, since rewards and penalties are based on the evaluation of performance (Rosen, 1981, p. 203). It is important to accurately evaluate performance in any position on the basis of criteria that are related to the position and that specify the critical elements of the position.

These criteria need to be identified in an appropriate manner. A good tool for developing them, already in use by some Korean government departments, would be the Balanced Scorecard model, which translates an organization's mission and strategy into a comprehensive set of performance measures that provide the framework for a strategic measurement and management system, which can be helpful in balancing multiple competing objectives and various aspects of performance. The scorecard measures organizational performance across four linked perspectives: financial, customer, internal business process, and learning and growth (Kaplan \& Norton, 1996, p. 18). The initiative by President George W. Bush to address results-oriented goals by emphasizing measurement and developing scorecards to track progress seems to be an application of the Balanced Scorecard model (cf. Nelson, 2004, p. 207).

Facilitating openness and competitiveness in public service would be another method to improve the competencies of senior executives and to utilize the private sector's business acumen. Promoting the flow of personnel between private and public sectors will facilitate the transfer and sharing of knowledge, skills, and information, and will foster the creation of better and faster solutions to problems (Namkoong, 2003, p. 53).

Third, we need to reflect deeply on whether it is suitable for the Korean SCS system 
to apply the third assumption, which emphasizes increased political control over the bureaucracy. There was some evidence that survey respondents perceived a decrease of merit system principles in the SES appointment process (Ring \& Perry, 1983, p. 135). It has been a matter of tradition and pride for career executives to do their best in executing policies once decisions are made (Rosen, 1981, pp. 203-204). Despite unfavorable reactions from some new bosses, it has been traditional for career executives to raise tough questions in an analytical approach (Rosen, 1981, p. 203). This has potentially heavy costs if bureaucrats' analytical approach and expertise are ignored and there is no room for resistance by career executives. The revised model by Perry and Miller (1991) provides strong support for traditional concerns about protecting the merit system from political interference. The results suggest that the avoidance of political abuses of the civil service promotes public confidence and an effective working climate within an agency (Perry \& Miller, 1991, p. 561).

It is very important to establish a climate that is favorable to the free and full exchange of differing views between career and political executives during decisionmaking processes (Rosen, 1981, p. 204). Undue political control over the bureaucracy can create heavy costs under some conditions. There should be more focus on political neutrality rather than political control over the bureaucracy in the design and operation of the Korean SCS system.

\section{CONCLUSION}

The central personnel agency and senior civil service system are key elements of the issue of how the public personnel administration should be organized and operated. Operation of both involves conflicts between values, and the organization of public personnel functions has been plagued by an attempt to realize several incompatible values at once; foremost among these values have been merit or neutral competence; executive leadership, political accountability, and managerial flexibility; and representativeness (Shafritz et al., 2001, p. 49).

According to the results of a survey of senior civil servants, candidates for the SCS, and a personnel specialist group, a consensus has built up that the value that the Korean government requires first is merit or neutral competence (KIPA, 2008, pp. 201, 250). To develop an effective civil service system, the political neutrality of civil servants must be preserved so that they can serve the best interest of the nation and its people, shielded from undue political influence and coercion (Kim, 1997, p. 92). If the corps of civil servants changes with each change of ruling party, it is difficult to retain highly qualified servants with appropriate levels of specialized knowledge and 
experience (Kim, 1997, p. 92). Achieving neutral competence thus requires the creation of a relatively independent agency to help insulate public employees from the partisan demands of political executives (Lee, 2008, p. 39; Shafritz et al., 2001, p. 49). However, this structural arrangement will tend to frustrate executive leadership and the ability of political executives to manage their agencies.

Professor Beryl A. Radin at the American University pointed out in her comments on the earlier drafts of this paper that the US system tried to balance competing values. These include attention to politics and attention to neutral technical competencies, centralization and decentralization, stability and ability to respond to new players and issues, control and flexibility, generalist and specialist views, and public- and privatesector values. It is never possible to ignore either value. Thus the US decisions always have inconsistencies within them.

Although merit should first be considered in devising a specific form for an independent central personal agency and in modifying the SCS system, other values should be balanced at the same time. Arrangements satisfying some values inevitably raise complaints that others are being inadequately achieved, and thus the civil service system has to be developed in a more elaborated form through debate and reflection.

\section{REFERENCES}

Ban, C., \& Red, H. C. III. 1990. The state of the merit system: Perceptions of abuse in the federal civil service. Review of Public Administration, 10(3): 55-72.

Brook, D. A., \& King, C. L. 2007. Civil service reform as national security: The Homeland Security Act of 2002. Public Administration Review, 67(3): 399-407.

Brook, D. A., \& King, C. L. 2008. Federal personnel management reform: From Civil Service Reform Act to national security reforms. Review of Public Personnel Administration, 28(3): 205-221.

Buchanan, B. 1981. The senior executive service: How we can tell if it works. Public Administration Review, 41(3): 349-358.

Campbell, A. K. 1978a. Civil service reform: A new commitment. Public Administration Review, 38(2): 99-103.

. 1978b. Revitalizing the federal personnel system. Public Personnel Management, 7(1): 59-64.

Cho, T., \& Hwang, H.-S. 2009. Management and performance of post merger integration programs in the Korean government. Seoul: Korea Institute of Public Administration.

Kaplan, R. S., \& Norton, D. P. 1996. Strategic learning and the balanced scorecard. 
Strategy \& Leadership, 24(5): 18-24.

Kim, J. Y. 1997. Direction for developing the Korean civil service system. Public Personnel Management, 26(1): 89-107.

KIPA (Korea Institute of Public Administration). 2008. A study on the improvement and evaluation of senior civil service system in Korean government. Seoul: Korea Institute of Public Administration.

Lah, T. J., \& Perry, J. L. 2008. The diffusion of the Civil Service Reform Act of 1978 in OECD countries: A tale of two paths to reform. Review of Public Personnel Administration, 28(3): 282-299.

Lee, C.-W., \& Im, Y.-J. 2009. Characteristics of government reorganization after democratization in Korea. Korean Review of Policy Sciences, 13(4): 1-17.

Lee, S.-W. 2008. Public management issues on the 2008 government reorganization by the Lee administration. Korean Public Management Review, 22(1): 27-47.

Long, N. E. 1981. The S.E.S and the public interest. Public Administration Review, 41(3): 305-317.

Namkoong, K. 2003. An evaluation of the results of open competitive position system program implementation in Korea. International Review of Public Administration, 8(1): 53-66.

2006. Civil service reform in the participatory government: Civil service system in transition. Paper presented at the Korean Association for Public Administration,

Nelson, S. 2004. The state of the federal civil service today. Review of Public Personnel Administration, 24(3): 202-215.

Nigro, F. A. 1979. The politics of civil service reform. Southern Review of Public Administration, 3(2): 196-239.

Nigro, F. A., \& Nigro, L. G. 1986. The new public personnel administration. Itasca, IL: F. E. Peacock.

Nigro, F. A., Nigro, L. G., \& Kellough, J. E. 2007. The new public personnel administration (6th ed.). Itasca, IL: F. E. Peacock.

Park, C.-O. 2009. The critical review of Korean government reorganization. Korean Review of Organizational Studies, 8(1): 1-30.

Park, C.-O. 2011. The perception of civil servants of the 2008 executive reorganization by the Lee Myongbak government. Korean Journal of Public Administration, 49(1): 1-30.

Perry, J. L., \& Miller, T. K. 1991. The senior executive service: Is it improving managerial performance? Public Administration Review, 51(6): 554-563.

Radin, B. 1997. Balancing policy and administrative change in the Clinton administration: The national performance review and the Government Result Act. In Y. H. 
Cho \& H. G. Frederickson (eds.), The White House and the Blue House. 11-35. University Press of America.

Ring, P. S., \& Perry, J. L. 1983. Reforming the upper levels of the bureaucracy: A longitudinal study of the senior executive. Administration \& Society, 15(1): 119-144.

Rosen, B. 1981. Uncertainty in the senior executive service. Public Administration Review, 41(2): 203-207.

Rosen, B. 1986. Crises in the US. civil service. Public Administration Review, 46(3): 207-214.

Shafriz, J. M., Rosenbloom, D. H., Riccucci, N. M., Naff, K. C., \& Hyde, A. C. 2001. Personnel management in government: Politics and process (5th ed.). New York: Marcel Dekker.

Shafriz, J. M., Rosenbloom, D. H., Riccucci, Rosenbloom, D. H., \& Hyde, A. C. 1992. Personnel management in government: Politics and process (4th ed.). New York: Marcel Dekker.

Thompson, F. J., \& Radin, B. A. 1997. Reinventing public personnel management: The Winter and Gore initiatives. In C. Ban \& N. M. Riccucci (eds.), Public personnel management. 3-20. New York: Longman.

West, W. F., \& Durant, R. F. 2000. Merit, management, and neutral competence: Lessons from the U.S. Merit Systems Protection Board, FY 1988-FY 1997. Public Administration Review, 60(2): 111-122.

Woodard, C. A. 2005. Merit by any other name-Reframing the civil service first principle. Public Administration Review, 65(1): 109-116.

Yeager, F. A. 1987. Assessing the Civil Service Reform Act's impact on senior manager work priorities. Public Administration Review, 47(5): 417-424.

Yun, K.-J. 2009. A comparison of administrative reform between Nicholas Sarkozy and Lee Myongbak government. Korean Public Administration Review, 43(2): 287-308.

http://ssl.jinji.go.jp/en/index.html

http://www.opm.gov/ses/recruitment/qrbprocess.asp\#admin 